\title{
SCREENING FOR FUNGICIDES WITH COMBINED EFFICACY AGAINST NECK BLAST AND SHEATH ROT IN RICE
}

\author{
RAJU M. R. B \\ Plant Pathology Section, Agricultural Research Station, Ragolu (Acharya N G Ranga Agricultural University) \\ Srikakulam District, Andhra Pradesh, India
}

\begin{abstract}
In afield experiment conducted at ARS, Ragolu (ANGRAU), Andhra Pradesh to identify a suitable fungicide for rice varieties susceptible to neck blast and sheath rot, selected fungicides (eight) were evaluated through foliar application for two times during crop growth period, at early panicle emergence and 10 days subsequently after first spray. Treatments, tricyclazole + mancozeb and trifloxystrobin + tebuconazole recorded pooled mean neck blast incidence of $1.9 \%$ each in comparison to $17.1 \%$ in untreated control. Whereas, trifloxystrobin + tebuconazole and propiconazole treatments were found effective against sheath rot recording 5.2 and $4.9 \%$ respectively in comparison to $15.0 \%$ mean sheath rot incidence in untreated plots. Present study indicates that higher returns (B:C ratio) could be realized in varieties susceptible to neck blast and sheath rot, through use fungicides trifloxystrobin + tebuconazole (B:C ratio of 1.53)/ tricyclazole + mancozeb (1.47) or propiconazole treatment (B:C ratio of 1.53:1). The study emphasis the need for selection of fungicides based on the varietal response to major diseases prevalent in a particular location.
\end{abstract}

KEYWORDS: Rice, Neck Blast, Sheath Rot, Fungicide, Trifloxystrobin + Tebuconazole \& Propiconazole

Received: Aug 25, 2020; Accepted: Sep 15, 2020; Published: Sep 30, 2020; Paper Id.: IJASRAUG202026

\section{INTRODUCTION}

Rice (Oryza sativa L.) is the predominant crop in the state of Andhra Pradesh. In the north coastal zone of Andhra Pradesh, paddy cultivation is constrained by a number of biotic and abiotic factors, among diseases, sheath blight, sheath rot and blast are significant (Anonymous, 2012). Blast disease of rice caused by Magnoporthe grisea is one of the devastating diseases causing significant crop losses in all paddy-growing areas of the world. The disease manifests at different crop stages as leaf blast, node blast and neck/ panicle blast, severity of blast disease is influenced by the prevailing climatic conditions, low night temperature coupled with high relative humidity whichfavourdevelopment of blast. Although, some growers, exploit varietal resistance to overcome the disease,in most instances, farmers grow locally popular rice varieties that are susceptible to blast. High yielding mega variety, Swarna (MTU 7029) is the predominant choice for most of the farmers in this part of Andhra Pradesh, the variety has high nitrogen responsiveness and is resistant to bacterial leaf blight, however, it is susceptible to blast.In the north coastal zone of Andhra Pradesh, late sowing during kharif coupled withcoincidence of flowering with low temperature months during panicle emergence, often results in significant crop loss due to neck blast.A number of fungicides, botanicals and biocontrol agents have been successfully used in different parts of the world for the management of neck blast (Gopi et al., 2016; Gohel \& Chauhan, 2015; Dutta et al., 2012). Similarly, chemical management of sheath rot through has also been documented (Deepmala et al., 2015; Pramod et al., 2012; Jagadeeshwar et al., 2015). However, in varieties susceptible to both neck blast and sheath rot, there is a need to 
identify chemicals with combined efficacy against of both the diseases. In many instances, neck blast and sheath rot diseases manifest during early panicle emergence and often results in partial to complete loss of panicle. Based on our understanding of nature of damage of these two diseases, losses could be avoided by following prophylactic chemical intervention. Keeping in view, the popularity of the Swarna variety, the present study was planned to identify a suitable fungicide for rice varieties susceptible to neck blast and sheath rot.

\section{MATERIALS AND METHODS}

Afield experiment was conducted for two year (2011-12 and 2012-13) in field No. 13C of Agricultural Research Station, Ragolu (Acharya N G Ranga Agricultural University) to identify a fungicide equally effective against both neck blast and sheath rot in paddy. Popular variety Swarna (MTU 7029) was used in the present study. The experiment was laid out in randomized block design with nine treatments each replicated thrice. Experiments were laid out with a plot size of $6.0 \mathrm{x}$ $2.25 \mathrm{~m}$ and adopting a spacing of $20 \times 15 \mathrm{~cm}$. Fertilizer were applied at recommended dose (80-60-50 NPK kg/ha).

In the study, eight fungicides were identified for evaluation against neck blast and sheath rot. Fungicidal sprays were planned for two times during the crop season, first at early panicle emergence stage and the second at 10 days after first spray. Data on the incidence of neck blast and sheath rot were recorded periodicallyafter the treatment imposition and expressed as per cent disease incidence. Total number of panicles and number of diseased panicles (sheath rot and neck blast) in an identified square meter of a given plot were recorded separately and expressed as per cent disease incidence using the formula.

Total no. of panicles - No. of diseased panicles

Disease incidence $=$ X 100

Total no. of panicles

Yield data from the individual plots was recorded and expressed as $\mathrm{Kg} / \mathrm{ha}$. Benefit cost ratiowas calculated considering the cost of cultivation (land preparation, Seed cost, nursery bed preparation, main field preparation, transplantation, weeding, fertilizer input costs, plant protection chemical cost, labour cost, irrigation, harvesting, transporting, winnowing and bagging) involved duringconduct of the experiment. Benefit cost ratio was calculated using the formula

Gross returns - Total cost of cultivation

Benefit cost ratio $=$ X 100

Total cost of cultivation

\section{RESULTS AND DISCUSSIONS}

During the two year study conducted for identification of a fungicide effective against two major disease constraintsviz., neck blast and sheath rot at panicle emergence in paddy var. Swarna, fungicidal treatments were imposed prophylactically for two times, first at early panicle emergence stage and the second at 10 days after first spray. Natural neck blast incidence of 10.6 and 23.6\% were recorded during 2011-12 and 2012-13 respectively (table 1). Among the fungicides, tricyclazole + mancozeb and trifloxystrobin + tebuconazole treatments recorded pooled mean neck blast incidence of $1.9 \%$ each in comparison to $1.8 \%$ recorded in tricyclazole treatment, these fungicides were found statistically at par with each other. 
Fungicides, zineb + hexaconazole, propiconazole and Kresoxim methyl were found marginally effective against neck blast.

From table 1, it evident that propiconazole followed by trifloxystrobin + tebuconazole and zineb + hexaconazole treatments were found effective recording mean pooled sheath rot incidence 4.9, 5.2 and $6.4 \%$ respectively in comparison to $15.0 \%$ sheath rot incidence recorded in untreated control.The findings of the present study were in agreement with earlier findings regarding the effectiveness of fungicides in sheath rot management (Pramod Kumar et al., 2012)

In the study, it was found that foliar application of fungicides at early panicle emergence resulted in significantly higher yields in comparison to untreated control $(3205 \mathrm{~kg} / \mathrm{ha})$. Trifloxystrobin + tebuconazole treatmentrecorded pooled mean yield of $4078 \mathrm{~kg} / \mathrm{ha}$ followed by propiconazole $(3963 \mathrm{Kg} / \mathrm{ha})$. Although tricyclazole was found effective against neck blast, the treatment did not result in significant reduction of sheath rot. Similarly, propiconazole found effective against sheath rot was found marginally effective against neck blast. Results of the present study, further suggest the need for fungicides with multiple modes of action for reducing the complex disease scenario (neck blast and sheath rot) existing post panicle emergence in paddy. The findings are supported by the study of Jagadeeshwar et al., (2015), regarding importance of fungicides in the management of location specific diseases

It is evident (table 2) that highest net returns were realized in trifloxystrobin + tebuconazole and propiconazole treatment $(\mathrm{B}: \mathrm{C}$ ratio of $1.53: 1)$ in comparison to $\mathrm{B}: \mathrm{C}$ ratio of $1.28: 1$ recorded in untreated control. $\mathrm{B}: \mathrm{C}$ ratio of 1.44 was recorded in tricyclazole treatment, whereas, tricyclazole + mancozeb treatment recorded a B:C ratio of 1.47:1. Among the fungicides, evaluated, kresoxim methyl and kasugamycin were found comparatively less effective both in terms of minimizing neck blast and sheath rot incidence and in yielding higher returns.

Table 2: Effect of Prophylactic Fungicidal Sprays on Improvement of Net Returns in Paddy (Benefit:Cost Ratio) Through Management of Neck Blast and Sheath Rot with Reference to var. Swarna - (Two Year Study)

\begin{tabular}{|c|l|c|c|c|c|}
\hline $\begin{array}{c}\text { S. } \\
\text { No. }\end{array}$ & \multicolumn{1}{|c|}{ Treatments } & $\begin{array}{c}\text { Cost of cultivation* } \\
\text { (Rs.) }\end{array}$ & $\begin{array}{c}\text { Gross returns } \\
(\text { Rs.) }\end{array}$ & Net returns (Rs.) & Benefit : Cost ratio \\
\hline 1 & Kresoxim methyl & 45000 & 59480 & 14480 & 1.32 \\
\hline 2 & $\begin{array}{l}\text { Trifloxystrobin }+ \\
\text { tebuconazole }\end{array}$ & 42538 & 65248 & 22710 & 1.53 \\
\hline 3 & $\begin{array}{l}\text { Zineb+ } \\
\text { hexaconazole }\end{array}$ & 41000 & 57686 & 16686 & 1.41 \\
\hline 4 & Kasugamycin & 42550 & 57762 & 15212 & 1.36 \\
\hline 5 & $\begin{array}{l}\text { Tricyclazole }+ \\
\text { mancozeb }\end{array}$ & 42070 & 61694 & 19624 & 1.47 \\
\hline 6 & Propiconazole & 41360 & 63406 & 22046 & 1.53 \\
\hline 7 & Tricyclazole & 41400 & 59599 & 18545 & 1.44 \\
\hline 8 & Isoprothiolane & 41300 & 59845 & 11131 & 1.45 \\
\hline 9 & Untreated control & 40150 & 51281 & & \\
\hline$*$ Figures indicated are the pooled mean of two years $(2011-12$ and 2012-13) & \\
\hline
\end{tabular}

\section{CONCLUSIONS}

The results of the twoyear study indicate that prophylactic foliar spray with trifloxystrobin + tebuconazole for two times, first at early panicle emergence stage and the second at 10 days after first spray resulted in higher returns through effective management of neck blast and sheath rot incidence in paddy. Foliar spray with propiconazole @ 1 ml/L followed by tricyclazole + mancozeb werealso found effective in minimizing diseases post panicle emergence and recorded a $\mathrm{B}$ :C ratio of 1.53 and 1.47 respectively. Results of the study, suggest the usefulness of fungicide formulation with broad spectrum of activity for effective management of neck blast and sheath rot in paddy. 


\section{REFERENCES}

1. Anonymous, 2012. Andhra Pradesh -3 (Ragolu). Production Oriented Survey, 2012. All India Coordinated Rice Improvement Programme. Directorate of Rice Research (ICAR), Rajendranagar, Hyderabad-500 030, India, 44-52

2. Chiejina, NNEKA V., and CHIEMEKA N. Onaebi. "In vitro fungicidal activity of two plant extracts against five phytopathogenic fungi of cucumber (Cucumissativus L.) fruit." International Journal of Applied and Natural Sciences 2 (2013): 359-401.

3. Deepmala, K., Rakesh, B.K. and Tiwari, P.K. 2015. Efficacy of fungicides for the management of sheath rot disease in rice under in vitro and in vivo conditions. Oryza- An International Journal on Rice, 52(3), 227-230

4. Dutta, D., Saha, S., Ray, D.P. and Bag, M.K. 2012. Effect of different active fungicides molecules on the management of rice blast disease. International Journal of Agriculture, Environment and Biotechnology, 5(3), 247-251

5. Fatma, Firdos, Aisha Kamal, and Alka Srivastava. "Morpho toxicity of fungicide mancozeb on two genotypes of Vigna. " J. Bot. $\operatorname{Res}$ (2017): 2277-4815.

6. Gopi, R., Avasthe, R. K., Kalita, H. and Kapoor, C. 2016. Management of Rice blast caused by Magnaporthe oryzae using botanicals, biocontrol agents and organically permitted fungicides. Indian Phytopathology, 69(1),10-15

7. Gohel, N.M. \& Chauhan, H.L. 2015. Integrated management of leaf and neck blast disease of rice caused by Pyricularia oryzae. African Journal of Agricultural Research, 10(10), 2038-2040

8. Pramod Kumar., Rai, R.C. and Rai, B. 2012. Evaluation of fungicides and biopesticides against sheath rot of rice. Oryza - An International Journal on Rice, 49(3), 212-214

9. Jagadeeshwar, R., Varma, N.R.G., Reddy, P.R.R., Raju, Ch.S., Vanisree, S., Gopal Reddy, B.G. and Dayakar, S. 2015. Screening of new fungicides against location specific diseases of rice occurring in southern Telangana zone of Andhra Pradesh. Journal of Research, ANGRAU, 42(1), 18

10. Singh, R., Sunder, S., Dodan, D.S. and Ram, L. 2011. Sources of Resistance to blast and its management through chemicals. Journal of Mycology and Plant Pathology, 41(3), 422-425

11. Meziane, M. A. L. I. K. A., and H. A. L. I. M. A. Goumri."The antimicrobial effect of extracts of Melia azedarach on some pathogenic microorganisms." Int. J. Appl. Nat. Sci 3 (2014): 173-180.

12. Meshram, R. E. E. N. A., and A. L. K. A. Chaturvedi."Effect of insecticide on in vitro pollen germination of Lycopersiconesculentum (Mill.)of F1 hybrid variety Laxmi." Int. J. Appl. Nat. Sci 6.4 (2017): 01-10.

Table 1: Effect of Fungicides on Incidence of Neck Blast and Sheath Rot in Paddy Var. Swarna (Pooled Data - 2011-12 and 2012-13)

\begin{tabular}{|c|c|c|c|c|c|c|c|c|c|c|c|}
\hline \multirow{2}{*}{$\begin{array}{l}\text { S. } \\
\text { No. }\end{array}$} & \multirow{2}{*}{ Treatments } & \multirow{2}{*}{$\begin{array}{c}\text { Dose (ml or } \\
\text { g/litre) }\end{array}$} & \multicolumn{3}{|c|}{$\begin{array}{c}\text { Neck blast Incidence } \\
(\%)\end{array}$} & \multicolumn{3}{|c|}{$\begin{array}{c}\text { Sheath rot Incidence } \\
(\%)\end{array}$} & \multicolumn{3}{|c|}{ Yield (Kg/ha) } \\
\hline & & & $\begin{array}{c}\text { 2011- } \\
12\end{array}$ & $\begin{array}{c}2012- \\
13\end{array}$ & $\begin{array}{c}\text { Pooled } \\
\text { Mean }\end{array}$ & $\begin{array}{c}\text { 2011- } \\
12\end{array}$ & $\begin{array}{c}2012- \\
13\end{array}$ & $\begin{array}{c}\text { Pooled } \\
\text { Mean }\end{array}$ & $\begin{array}{c}2011- \\
12\end{array}$ & $\begin{array}{c}2012- \\
13\end{array}$ & $\begin{array}{l}\text { Pooled } \\
\text { Mean }\end{array}$ \\
\hline 1 & $\begin{array}{l}\text { Kresoxim } \\
\text { methyl }\end{array}$ & 1.0 & $\begin{array}{c}4.7 \\
(12.4) \\
*\end{array}$ & $\begin{array}{c}11.7 \\
(20.0)\end{array}$ & $\begin{array}{c}8.2 \\
(16.2)\end{array}$ & $\begin{array}{c}11.1 \\
(19.4)\end{array}$ & $\begin{array}{c}4.2 \\
(11.8)\end{array}$ & $\begin{array}{c}7.6 \\
(15.6)\end{array}$ & 3659 & 3776 & 3717 \\
\hline 2 & $\begin{array}{l}\text { Trifloxystrobin } \\
+ \text { tebuconazole }\end{array}$ & 0.4 & $\begin{array}{c}1.0 \\
(5.8)\end{array}$ & $\begin{array}{l}2.8 \\
(9.5)\end{array}$ & $\begin{array}{l}1.9 \\
(7.7)\end{array}$ & $\begin{array}{c}6.2 \\
(14.4)\end{array}$ & $\begin{array}{c}4.3 \\
(11.9)\end{array}$ & $\begin{array}{c}5.2 \\
(13.1)\end{array}$ & 4052 & 4104 & 4078 \\
\hline 3 & $\begin{array}{l}\text { Zineb } \\
\text { hexaconazole }^{+}\end{array}$ & 2.0 & $\begin{array}{c}5.0 \\
(12.9)\end{array}$ & $\begin{array}{c}13.8 \\
(21.8)\end{array}$ & $\begin{array}{c}9.4 \\
(17.4)\end{array}$ & $\begin{array}{c}7.2 \\
(15.5)\end{array}$ & $\begin{array}{c}5.6 \\
(13.7)\end{array}$ & $\begin{array}{c}6.4 \\
(14.6)\end{array}$ & 3754 & 3467 & 3611 \\
\hline 4 & Kasugamycin & 1.0 & $\begin{array}{c}2.2 \\
(8.2)\end{array}$ & $\begin{array}{c}5.8 \\
(13.9)\end{array}$ & $\begin{array}{c}4.0 \\
(11.1)\end{array}$ & $\begin{array}{c}12.6 \\
(20.8)\end{array}$ & $\begin{array}{c}7.9 \\
(16.3)\end{array}$ & $\begin{array}{c}10.3 \\
(18.0)\end{array}$ & 3653 & 3558 & 3605 \\
\hline
\end{tabular}




\begin{tabular}{|c|c|c|c|c|c|c|c|c|c|c|c|}
\hline 5 & $\begin{array}{l}\text { Tricyclazole + } \\
\text { mancozeb }\end{array}$ & 2.0 & $\begin{array}{c}0.9 \\
(5.5) \\
\end{array}$ & $\begin{array}{c}3.0 \\
(9.6) \\
\end{array}$ & $\begin{array}{c}1.9 \\
(7.5) \\
\end{array}$ & $\begin{array}{c}9.2 \\
(17.7) \\
\end{array}$ & $\begin{array}{c}6.1 \\
(14.3) \\
\end{array}$ & $\begin{array}{c}7.7 \\
(15.9) \\
\end{array}$ & 3982 & 3736 & 3859 \\
\hline 6 & Propiconazole & 1.0 & $\begin{array}{c}6.8 \\
(15.0)\end{array}$ & $\begin{array}{c}11.2 \\
(19.5)\end{array}$ & $\begin{array}{c}9.0 \\
(17.3)\end{array}$ & $\begin{array}{c}5.5 \\
(13.5)\end{array}$ & $\begin{array}{c}4.4 \\
(12.1)\end{array}$ & $\begin{array}{c}4.9 \\
(12.7)\end{array}$ & 3906 & 4020 & 3963 \\
\hline 7 & Tricyclazole & 0.6 & $\begin{array}{c}1.0 \\
(5.7)\end{array}$ & $\begin{array}{c}2.6 \\
(9.3) \\
\end{array}$ & $\begin{array}{c}1.8 \\
(7.5) \\
\end{array}$ & $\begin{array}{c}11.7 \\
(20.0) \\
\end{array}$ & $\begin{array}{c}7.5 \\
(15.9) \\
\end{array}$ & $\begin{array}{c}9.6 \\
(17.9)\end{array}$ & 3792 & 3833 & 3812 \\
\hline 8 & Isoprothiolane & 1.5 & $\begin{array}{c}2.8 \\
(9.5)\end{array}$ & $\begin{array}{c}5.5 \\
(13.4)\end{array}$ & $\begin{array}{c}4.1 \\
(11.5)\end{array}$ & $\begin{array}{c}12.2 \\
(20.5)\end{array}$ & $\begin{array}{c}8.1 \\
(16.5)\end{array}$ & $\begin{array}{c}10.1 \\
(18.4)\end{array}$ & 3773 & 3707 & 3740 \\
\hline 9 & $\begin{array}{l}\text { Untreated } \\
\text { control }\end{array}$ & 0 & $\begin{array}{c}10.6 \\
(18.9)\end{array}$ & $\begin{array}{c}23.6 \\
(29.1)\end{array}$ & $\begin{array}{c}17.1 \\
(24.0)\end{array}$ & $\begin{array}{c}16.3 \\
(23.8)\end{array}$ & $\begin{array}{c}13.7 \\
(21.7)\end{array}$ & $\begin{array}{c}15.0 \\
(22.7)\end{array}$ & 3438 & 2972 & 3205 \\
\hline & & $\mathrm{CV}(\%)$ & 13.3 & 11.6 & 8.3 & 7.5 & 18.4 & 10.1 & 7.2 & 8.9 & 6.1 \\
\hline & & $\mathrm{CD}(0.05)$ & 2.4 & 3.2 & 1.9 & 2.4 & 4.6 & 2.9 & 464 & 487 & 393 \\
\hline
\end{tabular}


